\title{
Bento Rodrigues: memória de um povoado destruído pela lama ${ }^{1}$
}

Cecília Bueno

Pontifícia Universidade Católica do Rio de Janeiro - PUC-Rio

Departamento de Comunicação Social - Bacharelado em Jornalismo

\section{RESUMO}

O artigo observa a memória de um povo devastado por uma tragédia ambiental, tendo como material de pesquisa depoimentos de antigos moradores do distrito de Bento Rodrigues (MG) para reportagem nossa, seis meses depois de ser destruído pela lama e rejeitos da mineradora Samarco, em 2016. Os entrevistados, que haviam perdido os referenciais físicos, constroem um novo espaço, simbólico, a partir dos relatos e das operações da memória. A pesquisa aponta para a importância do registro jornalístico de lembranças de uma comunidade para sua história.

\section{PALAVRAS-CHAVE}

Memória; Tragédia; Desterritorialização; Jornalismo; Bento Rodrigues.

\section{Introdução}

No dia 5 de novembro de 2015, o rompimento de uma barragem de rejeitos de minério provocou uma onda de lama que varreu, em menos de uma hora, o subdistrito de Bento Rodrigues, em Minas Gerais. A lama percorreu 663 quilômetros em 17 dias e arruinou outros sete distritos de Mariana, contaminou os rios Gualaxo do Norte e do Carmo, chegou à foz do Rio Doce e atingiu o mar no Espírito Santo. Deixou um rastro de devastação em dois estados e 40 municípios. No total, 19 pessoas morreram na maior tragédia ${ }^{2}$ ambiental brasileira até então.

Localizada na zona rural, a 35 quilômetros do centro da cidade de Mariana, Bento Rodrigues é uma terra arrasada. O vilarejo estava no centro das atividades de mineração do país. A barragem do Fundão havia sido construída para acomodar os rejeitos provenientes da extração do minério de ferro que são retirados de extensas minas na região. Fazia parte da

\footnotetext{
1 Artigo derivado de monografia de graduação em Jornalismo, orientada pela professora Itala Maduell Vieira e apresentada em julho de 2019.

${ }^{2}$ A classificação de tragédia para eventos como o ocorrido em Mariana e Brumadinho é problematizada e historicizada por Alice Melo em sua tese de doutorado em Comunicação. Ver Melo (2018).
} 
Mina Germano, controlada pela Samarco Mineração S.A., um empreendimento conjunto das duas maiores empresas de mineração do mundo, a brasileira Vale S.A. e a anglo-australiana BHP Billiton.

As ruínas que sobraram das 200 casas onde moravam 600 pessoas estão cobertas por uma grossa superfície de lama matizada em vermelho e marrom. De acordo com a Fundação Renova, criada pelas mineradoras envolvidas para pagar indenizações e realizar obras de recuperação, a barragem abrigava cerca de 56,6 milhões de $\mathrm{m}^{3}$ de lama de rejeito. Parte, 4,5 milhões de $\mathrm{m}^{3}$, ficou represada na área da Samarco. Os 43,7 milhões de $\mathrm{m}^{3}$ de rejeitos tóxicos que vazaram da barragem formaram um tsunami de 2,5 metros de altura. Soterraram $80 \%$ das edificações de Bento Rodrigues.

Os moradores partiram das casas só com a roupa do corpo e subiram para as partes mais altas da cidade. Muitos acharam que logo voltariam. As famílias foram realocadas em abrigos provisórios nas casas e pousadas de Mariana. Ainda hoje esses moradores aguardam a construção do Novo Bento. O povoado vai ser erguido em um novo local, conhecido como Lavoura, escolhido por meio de votação em maio de 2016 pelos moradores. A Fundação Renova, responsável pelas obras, já alterou três vezes a data de inauguração da nova sede do subdistrito de Bento Rodrigues: primeiro para 2018, depois para março de 2019, e atualmente é aguardada para o segundo semestre de 2020, mais de cinco anos após a tragédia (VALE e RICCI, 2019).

Os moradores de Bento se deparam abruptamente com o fim do povoado, que existia há 317 anos. Após o desastre, histórias escritas no espaço físico foram removidas, deslocadas de lugar, apagadas. Casas, escolas, lojinhas, fotografias, livros e cadernos estão sepultados sob terra. O mundo real e simbólico conhecido pelos moradores da localidade foi destruído. Uma nova realidade é apresentada. A relação do homem de Bento com o mundo é reiniciada. A história começa a se reescrever a partir do vazio simbólico, depois de uma ruptura no mundo físico.

O objetivo deste artigo é observar a memória de um povo devastado pela tragédia ambiental, tendo como material de pesquisa depoimentos de antigos moradores do município de Bento Rodrigues a uma jornalista. O trabalho existe para reforçar a importância do registro jornalístico de lembranças de uma comunidade para sua história. A pesquisa recolhe e analisa os relatos e as histórias do antigo povoado. Os entrevistados haviam perdido todos os referenciais físicos do passado. A cidade volta a existir na bricolagem da memória coletiva, construindo um novo espaço de memória. O estudo se baseia em depoimentos coletados para 
uma reportagem nossa seis meses após a tragédia, em abril de 2016, para o Jornal da PUC Online (BUENO, 2016), sobre como moradores reagiam ao súbito desaparecimento de Bento e ao deslocamento para um espaço novo e desconhecido.

O artigo registra as impressões e as memórias de moradores que realizam romarias em direção às ruínas. Todos os depoimentos de moradores são referentes ao mês de abril de 2016, quando foram coletados. Essas narrativas serão tratadas a partir do estudo da memória, como Maurice Halbwachs (1990), Pierre Nora (1993) e Aleida Asmann (2011). Entre os temas estudados, estão os conceitos de fim do passado e a relação de perda do território; a memória de locais e de objetos; e os conceitos de enraizamento e de desterritorialização da memória.

\section{Romaria na terra arrasada ou o fim do passado}

Bento Rodrigues desapareceu para seus antigos moradores em 15 minutos. O distrito que nasceu no século XVIII da atividade mineradora se enterrou em lama vermelha, junto com o passado de seus moradores. Com o apagamento do passado, os antigos moradores da comunidade desenvolvem imediatamente uma nova consciência sobre a vida. Mesmo com o desaparecimento dos referenciais físicos, as pessoas ainda se encontram presas a tradição de seus costumes e ao mundo simbólico que construíram ao longo de uma vida na comunidade. Em A memória coletiva (1990), o sociólogo Maurice Halbwachs conclui que "a lembrança é, em larga medida, uma reconstrução do passado com a ajuda de dados emprestados do presente" (HALBWACHS, 1990, p.71).

Halbwachs se refere às modernizações de uma cidade ao longo do tempo. A volta ao lugar transformado é importante para que lembranças possam ser localizadas. No caso de Bento, a transformação foi destruição, e a cidade virou ruína em instantes. Halbwachs afirma que, quando uma sociedade é submetida a uma modificação profunda, caso da população de Bento, a "memória atinge por dois caminhos diferentes as lembranças que correspondem a esses dois períodos sucessivos e não volta, de um para o outro, de modo contínuo" (1990, p.126). Segundo ele, o passado destruído e o presente se conservam como dois quadros de pensamento distintos. A vivência dos dois simultaneamente é necessária para que as memórias possam ser localizada:

Para reencontrar caminhos e monumentos antigos, conservados, aliás, ou desaparecidos, guiamo-nos pela planta geral da cidade antiga, transportamo-nos em pensamento até lá, o que é sempre possível 
àqueles que ali viveram [...]. Na cidade moderna em si mesma encontramos particularidades da cidade antiga, porque temos olhos e pensamentos somente para esta. Assim, quando numa sociedade que se transformou subsistem vestígios de que existia antes, aqueles que a conheceram em seu estado primeiro podem também deter sua atenção sobre esses traços antigos que lhes dão acesso a um outro tempo e a um outro passado. (HALBWACHS, 1990, p. 126-127)

Como observado durante a incursão para a reportagem em 2016, os moradores de Bento continuam voltando cotidianamente ao povoado enterrado sob a lama. Eles extraem da lama a sublimação de ver, em vez de escombros, uma cidade que ainda está lá. Uma outra Bento, reconstruída pelas memórias projetadas naquele deserto.

Cristiano Sales era motorista de uma linha de ônibus que transportava funcionários da Vale. Todos os dias, fazia o mesmo trajeto: saía do trabalho em Mariana às $14 \mathrm{~h}$ e cumpria os 35 quilômetros rumo ao distrito de Bento Rodrigues, onde morava com os pais. No dia do incidente, um atraso salvou-Ihe a vida. Quando chegou ao alto da colina de onde pode se ver parte do vilarejo, sentiu um cheiro forte de enxofre e desconfiou que fosse da mineradora. Estava a 200 metros da entrada de Bento quando viu a lama descer da Barragem do Fundão e arrasar tudo. "Se eu estivesse dois minutos adiantado, tinha ido embora na lama", disse Sales, que viu o sino da igreja badalar pela última vez, enquanto era carregada pela enxurrada. Desde então, Cristiano refaz frequentemente o trajeto que percorria todos os dias antes do desastre:

De vez em quando, saio do trabalho e vou para Bento. Faço isso para ver que aconteceu. Porque tem hora que acho que não aconteceu. A ferida não cicatriza. Então volto para lembrar. Falam que Bento acabou. Mas, para mim, não acabou, não. Eu volto lá e vejo. Sinto-me bem em ir lá e ver. Mesmo que esteja tudo destruído. Voltei lá pela primeira vez depois de um mês. Nossa, não tem nem explicação. Perdemos tudo. Eu vou porque sinto falta de casa. Não tem como esquecer do lugar, minha noção de lar estava lá. Entro lá, vou nos lugares, vou onde era a igreja. Pra lembrar. Tem que lembrar, né? Graças a Deus a gente ficou vivo e isso não deixou apagar essa memória da gente. Apagar não apaga. Ali não acaba, não. Aquilo vai ficar pro eterno. (BUENO, 2016)

No feriado de Tiradentes de 2016, quase seis meses após o incidente, alguns moradores voltaram às ruínas. Do alto da cidade e do mesmo lugar de onde assistiu ao percurso da lama, Sales disse: "Antigamente, chegava aqui e pensava "Ufa, estou em casa". Do alto, dava para ver toda a cidade. Hoje, vemos pedaços de Bento espalhados pelo pasto de lama" (BUENO, 2016). 
"Ali que era a casa da vó?", pergunta Ingrid, de 11 anos, à mãe, Lucinéia Silveira. A inevitável dificuldade em identificar algo próximo ao vestígio de uma casa deixou a menina sem uma resposta concreta. Mas, de alguma maneira, elas encontram certo conforto no garimpo de fragmentos de um mundo plausível, como diz Halbwachs: "Numa sociedade que se transformou subsistem vestígios de que existia antes, aqueles que a conheceram em seu estado primeiro podem também deter sua atenção sobre esses traços antigos que Ihes dão acesso a um outro tempo e a um outro passado" (HALBWACHS, 1990, p.127).

Weberson Santos chega logo depois. Usa boné e traz uma mochila nas costas. Quer refazer o trajeto da lama, à cata de algum pertence. Ele conta que quer encontrar seu tablet, para tentar recuperar o cartão de memória. "Ali eu havia registrado o passo a passo da construção da minha casa, as fotos dos meninos, da Primeira Comunhão... Agora me resta correr atrás dessas lembranças" (BUENO, 2016).

Para driblar a fiscalização nas áreas de acesso proibido, passam por trilhas alternativas às escondidas. Para entrar no distrito sem que os seguranças percebam, Weberson atravessa o riacho que corta Bento. Só não consegue escapar dos lembretes do desastre que se estendem, sob diversas formas, na região: partículas de minério acumuladas no fundo do leito brilhavam ao sol.

Halbwachs afirma que "quando um grupo humano vive muito tempo em um lugar adaptado a seus hábitos, não somente os seus movimentos, mas também seus pensamentos se regulam pela sucessão das imagens que the representam os objetos exteriores" (HALBWACHS, 1990, p.136). Enquanto caminha no barro vermelho e seco, Weberson conta sobre a antiga rotina, os fins de semana no bar da Sandra, as conversas com amigos na pracinha, as festas de igreja. Recordações pulsantes, como o esforço quase diário de escavar o passado no monte barrento antes chamado de lar.

Ao reencontrar a rua onde toda a família morava, ele fala como se tudo ainda existisse. "Ali é a casa do meu primo, lá é a casa da minha cunhada. Mais ali é a casa da minha irmã. A minha casa é aqui, a piscina fica aqui".

Quando um grupo está inserido numa parte do espaço, ele a transforma à sua imagem, ao mesmo tempo em que se sujeita às coisas que a ele resistem. Ele se fecha no quadro que construiu. A imagem do meio exterior e das relações que estáveis que mantém consigo passa ao primeiro plano da ideia que faz de si mesmo. Ele penetra todos os elementos de sua consciência, comanda e regula sua evolução. [...] Não é o indivíduo isolado, é o indivíduo como membro 
do grupo, é o próprio grupo que, dessa maneira, permanece submetido à influência da natureza material e participa de seu equilíbrio. [...] Quando os membros de um grupo estão dispersos e não encontram nada, em seu novo ambiente material, que Ihes lembra a casa e os quartos que deixaram, se permaneceram unidos através do espaço, é porque pensam nesta casa e nestes quartos. (HALBWACHS, 1990, p.133)

Diante do vazio da perda, Weberson é coberto por uma anestesia ao rever o que resta da casa na qual morara e a qual ajudara a construir. "Dá uma sensação de incapacidade. O cérebro fica neutro, a gente não consegue pensar nem positivo, nem negativo. Parece que o cérebro fica paralisado". Depois de procurar por duas horas, em vão, o tal tablet e outros resquícios tangíveis da vida em Bento, Weberson desiste. Ao longe, vê os pais e mais seis familiares descendo o morro para atravessar o riacho rumo a Bento. Dali a pouco chegam outras pessoas. Carregam enxadas. Também cumprem a sina de remexer as sobras das antigas casas em busca de migalhas do passado.

A movimentação dos outros antigos moradores é percebida por um segurança, que se posiciona para impedir o acesso dos moradores. Determinados, gritam que "ninguém os impedirá de entrar". Evocam o direito a propriedades que, embora tenham ingressado num inventário intangível, estão vivas tanto na memória quanto na batalha por ressarcimentos. "Ah, vamos entrar aí, sim. Isso aí é nosso ainda. Não recebemos nenhum dinheiro pelas nossas terras", argumenta um. "Ninguém vai conseguir me tirar daqui. Hoje eu entro na minha casa de qualquer jeito", esbraveja outro. "Liga para a Samarco e fala que o povo do Bento chegou", ironiza mais outro (BUENO, 2016).

Os costumes de um grupo resistem às forças que tendem a transformá-los. Tal resistência demonstra que as imagens espaciais são sustento da memória coletiva. As cidades acabam sempre se transformando no curso da história. Por consequência de um incêndio, de uma ocupação militar, ou, no caso de Bento Rodrigues e Brumadinho, de uma avalanche de lama, "quarteirões são destruídos e não mais existem, a não ser em estado de ruínas... Velhas casas desabam lentamente... os planos de sobrepõem uns aos outros... O centro se desloca" (HALBWACHS, 1990, p.136). 


\section{Memória de locais e objetos}

O filósofo Cícero disse: "Grande é a força da memória que reside no interior dos locais". O mar barrento afogou a casa de Paula Alves. Na primeira vez que voltou ali, ela conta que teve medo de entrar na casa onde morou por 36 anos. "Chegar e ver tudo destruído, não ver ninguém... Ah, ficou uma escuridão, né, ficou uma tristeza, fiquei com medo de entrar dentro de casa porque estava escuro. E antes tinha vida ali, tinha luz" (BUENO, 2016). Halbwachs elucida por que nos apegamos aos objetos e por que desejamos que eles não mudem e continuem a nos fazer companhia. "Nossa casa, nossos móveis e a maneira segundo a qual estão dispostos, o arranjo dos cômodos onde vivemos, lembram-nos da nossa família e os amigos que víamos geralmente nesse quadro" (1990, p.131). Apesar de estranhar a velha casa, toda vez que volta, Paula sente vontade de "limpar tudo e ficar por lá". Se pudesse, levaria duas coisas para si: a escada de pedra e o pé de manacá plantado pelo avô na frente da casa, ambos centenários. "A única coisa irreparável é a vida. Se a gente não perdeu a vida, do resto das coisas a gente vai correndo atrás", diz Paula com um leve sorriso no rosto.

Assman observa que o que favorece determinados locais de um poder de memória é, principalmente, sua ligação fixa e duradoura com histórias de família. Para exemplificar o fenômeno dos "locais da família" ou "locais de gerações", ela cita o escritor americano Nathaniel Hawthorne no esboço autobiográfico que ele fez preceder a seu romance $A$ letra escarlate (1850): "Essa longa relação de uma família com um lugar, berço e túmulo, cria entre ele e os entes humanos" (ASMANN, 2011, p.320).

Orides da Paixão de Sousa tem 84 anos. Morava com os três filhos e oito netos, todos na mesma casa em Bento. Diferente da maioria dos antigos vizinhos de Bento, Orides não voltou à terra arrasada. O que ela queria de lá, mesmo, ninguém achou: o retrato do falecido marido, "única lembrança que guardava de Raimundo". "Não quero voltar para lá, para não ver nada. Ficar sem ir lá é melhor. Assim a gente vai esquecendo as coisas. Tudo que eu tinha de valor foi embora" (BUENO, 2016).

A casa de Eliene Geralda dos Santos, diretora da Escola Municipal de Bento Rodrigues, ficava em uma rua que não foi completamente atingida pela lama. Ela morava com o marido e o filho em uma casa de dois andares. A primeira preocupação foi o álbum de fotografias de seu filho, que o marido conseguiu recuperar da primeira vez que voltou à casa. Eliene sente falta de sua casa e de como ela foi construída. Começou a projetá-la quando ainda namorava. A casa começou pequena só para se casarem, mas o sonho dos dois era ter uma casa de dois andares. As obras começaram em 2013. O próprio marido construía a casa nos fins de 
semana. Pouco tempo depois de acabado o novo quarto do casal - "enorme, do jeito que sempre sonhei" -, veio a lama.

Assman também teoriza que, superando o esquecimento coletivo, alguns lugares viram monumentos de preservação de memória:

Após intervalos de suspensão da tradição, peregrinos e turistas do passado retornam a locais significativos para eles, e ali encontram uma paisagem, monumentos ou ruínas. Com isso ocorrem "reanimações", nas quais tanto o lugar reativa a recordação quanto a recordação reativa o lugar. (ASMANN, 2011, p.25)

Um processo de tombamento iniciado pelo Conselho do Patrimônio de Mariana abriu um debate sobre a criação de um memorial nas comunidades. Alguns imóveis, como a Igreja de Nossa Senhora das Mercês (Bento Rodrigues) e a Igreja de Santo Antônio (Paracatu), foram tombados. Um dossiê produzido pela Escola de Arquitetura da Universidade Federal de Minas Gerais (UFMG) propõe o tombamento da região do distrito de Bento Rodrigues. Pedido de tombamento da região e de transformação do local em um sítio de memória sensível aguarda avaliação (AGÊNCIA BRASIL, 2019).

\section{Enraizamento/situações de deslocamento}

Halbwachs afirma que, mesmo em situações que não são catastróficas, quando algum acontecimento determina algum tipo de transporte para um espaço novo, antes de haver a adaptação, o homem deslocado atravessa um período de incerteza, como se tivesse deixado para trás toda sua personalidade. E cita Auguste Comte, que observou "que o equilíbrio mental decorre em boa parte e, primeiro, pelo fato que os objetos materiais com os quais estamos em contato diária mudam pouco, e nos oferecem uma imagem de permanência e estabilidade" (HALBWACHS, 1990, p.131). Essa estabilidade de uma sociedade imóvel tem a ver com o conceito de enraizamento, criado por Simone Weil. A escritora Eclea Bosi diz que "o ser humano tem uma raiz por sua participação real numa coletividade, que conserva vivos certos tesouros do passado e certos pressentimentos do futuro. O desenraizamento a que nos obriga a vida moderna é uma condição desagregadora da memória" (BOSI, 2012, p. 199).

Os moradores de Bento relatam sofrer preconceitos dos habitantes da cidade para onde foram levados. Paula Alves comenta que Mariana vive uma crise econômica e, segundo ela, Bento já sofria as consequências disso. Ela conta que o pessoal da cidade culpou a comunidade do povoado pela 
tragédia e por essa crise. Ela tem medo de sair, e reclama que as pessoas na rua falam mal dos novos alocados na cidade. "Falam que quando a gente sair daqui vão jogar muito álcool e água sanitária para limpar a cidade. Por isso só vou do serviço pra casa, pra casa pro serviço".

Paula passou a morar com os pais e com o filho João Pedro em uma casa alugada pela Samarco, no centro de Mariana. As vítimas da tragédia recebem da mineradora um auxílio financeiro geral de $\mathrm{R} \$ 1.800$ por mês, mais $20 \%$ deste valor para cada integrante da família. Ainda assim, mostra-se incomodada com o novo custo de vida e as novas rotinas: "Uma folha de couve aqui custa 1 real. Lá em Bento, a gente não comprava nada" (BUENO, 2016). A casa onde morava com a família em Bento Rodrigues foi uma das últimas a ser atingida pela enxurrada de lama. Tinha um pomar e uma horta onde plantavam couve, alface, almeirão, tomate, cebola, limão, laranja, ameixa, pêssego. Hoje, na casa alugada, plantam apenas tomate e jiló. Não há espaço para ter uma horta.

Depois da tragédia, Paula continua trabalhando para a mineradora. Hoje ela cuida do galpão com cachorros resgatados em Bento e em Paracatu de Baixo. Limpa, lava, trata e passeia com os animais. Conta que no começo não gostava muito, mas reconhece que a nova função ajuda, ao lado dos amigos e parentes, a ocupar a cabeça e a estimulá-la a seguir em frente. "Tem hora que lembro, dá saudade, aí a gente vê o mato ao redor e fica lembrando de Bento". Ela declara:

Sinto falta de tudo, nos mínimos detalhes. Sinto falta até do fogão de lenha, da serpentina. A gente tomava banho em serpentina. Toda folga, eu gostava de buscar lenha. Sinto falta de ir em casa à tarde, de dar uma volta com minha motinha, ir na rua, na casa da minha irmã. Gostava mais de ficar com minha família, nós somos seis irmãos. Tudo para nós era motivo de festa. Lá a gente fazia muitas festas, final de semana, e, às vezes, até dia de semana a gente cismava de tomar uma cervejinha e comer uma carninha. Eu queria criar meu filho lá. Ele está com 5 anos. Eu queria ensinar pra ele o que meus pais me ensinaram lá. (BUENO, 2016)

O pai de Paula, Antônio Alves, de 70 anos, morou em Bento a vida toda. Todos os dias, acordava cedo, regava a horta, tratava das galinhas, capinava o quintal, cuidava do pomar. Segundo ele, vida de roceiro. "Tudo o que conheço está no Bento, meu avô nasceu lá". Hospedado em Mariana, capinou os quintais de duas casas, menos pelo dinheiro e mais na tentativa de reviver a antiga rotina. Um problema de saúde o impediu de continuar. "Rezo, agradeço a Deus por mais um dia e fico andando pela casa. Às vezes, saio na rua. Mas fico cismado e com medo. Na cidade, você não sabe quem está ao seu redor. Não sabe quem é gente do bem" (BUENO, 2016). 
O filho de Paula, João Pedro, de 5 anos, mudou completamente a rotina. Em Bento, estudava de manhã e à tarde brincava com os amigos, andava de bicicleta e ajudava o avô na horta. Agora estuda à tarde e, separado dos colegas, encontra companhia na televisão. Paula conta que nas férias foi pior, porque ele sentiu falta dos coleguinhas, que agora não moram mais perto. "Quando nos mudamos para cá, João tinha medo de vento, de chuva e de caminhão. Achava que era o barulho da barragem estourando. Outro dia, ele perguntou assim para mim: "Mamãe, aqui em Mariana não tem barragem, né? Porque eu não quero correr mais, não".

Cristiano Sales também revela sua dificuldade de readaptação:

Até hoje estou aqui em Mariana, mas falar que eu estou bem, eu não estou. Porque final de semana não tem como sair. No domingo todo mundo sentava com os colegas na praça, se reunia e ficava quieto. Hoje para encontrar as pessoas é difícil. Eu moro no Rosário [bairro em Mariana], o outros moram na Colina [bairro em Mariana]. A gente telefona pros colegas, vai tentando encontrar em barzinho, jogar futebol, mas encontrar igual encontrava lá não tem jeito. Não sei muito bem o que fazer pra superar. Porque a gente está perdido, né? Eu trabalho. Imagina meu pai, que só fica dentro de casa. Eu tento superar isso no serviço, fico trabalhando, final de semana encontro com os colegas e a gente vai levando a vida. (BUENO, 2016)

Eliene conta que, no começo, seu filho sentia muita falta de casa. "Demorou 45 dias para se adaptar, chorava sempre e falava 'bobora'". Não dormia na acomodação arranjada pela mineradora para a família. O marido conseguiu recuperar o berço que estava no segundo andar da casa. Logo na primeira noite, ele dormiu. Recentemente, Eliene falou a palavra "Bento" e o menino retrucou: "barro". Ela acredita que ele deve ter associado a algum comentário da época da tragédia. O marido conseguiu recuperar brinquedos do menino. Depois de 12 dias em um hotel, a família de Eliene foi para um apartamento. Ela só queria retomar a vida.

Vamos refazer a vida, eu tenho filho para criar, não posso ficar doente agora porque eu fui vítima dessa tragédia. Ou você escolhe ficar preso a isso o resto da vida ou você vai refazer sua história. E eu quero refazer, meu filho tá bem, minha mãe tá bem. No momento da tragédia, o que pesou pra qualquer um que tava lá era se a família estava bem. Depois que você descobre que está tudo bem, nada mais importa. Sinto saudades, é claro. A gente tem lembranças. Mas eu quero me lembrar só das coisas boas que eu vivi lá. (BUENO, 2016)

Eliene enumera as saudades: da infância, de brincar no campinho com os primos, da escola em que estudou e da qual foi diretora e do dia do seu casamento:

De tudo que aconteceu, eu ainda tenho esperança. A vida é mais importante. Bento acabou, mas a história dele não. A gente é 
protagonista de uma história ruim, mas a gente tem que sair dela. Essa história não pode me seguir até o final da minha vida. Eu fui vítima de uma tragédia, mas eu escapei dela, eu escapei da morte. (BUENO, 2016)

No dia 7 de maio de 2016, 223 das 226 famílias do distrito escolherem o terreno conhecido como Lavoura para a construção de Novo Bento. A área 350 hectares (3,5 quilômetros quadrados) fica a oito quilômetros de Mariana e a nove da antiga Bento Rodrigues. "Pelo menos, esse lugar fica no trajeto que era da gente. No mesmo sentido de Bento", diz Paula. Com os atrasos nos prazos de entrega, espera-se que novo Bento Rodrigues fique pronto em agosto de 2020. As obras das 100 primeiras casas devem ser iniciadas em 15 de julho de 2019. Os trabalhos de terraplanagem estão em fase final. A estabilização dos terrenos das residências e da escola, assim como a implantação da infraestrutura subterrânea das redes de drenagem pluvial e esgoto, estão em andamento (VALE e RICCI, 2019). A escritora Eclea Bosi fala sobre a importância de projetos urbanos terem como princípio a memória de moradores:

Eu penso que os urbanistas quando fazem projetos sobre as cidades, deveriam escutar os velhos moradores e estarem abertos a sua memória, que é a memória de cada rua, de cada bairro. Eles estariam recuperando a dimensão humana do espaço que é um problema político dos mais urgentes. A sobrevida de um grupo se liga estreitamente a morfologia da cidade e essa ligação se desarticula quando a especulação urbana causa um grau intolerável de desenraizamento. Há nos habitantes do bairro o sentimento de pertencer a uma tradição, a uma maneira de ver que anima a vida das ruas, das praças, dos mercados e das esquinas. $E$ tudo isso se reflete bem nos depoimentos dos nossos memorialistas. Então, os pesquisadores devem ter a consciência de que uma história de vida que nós escutamos não é feita para ser arquivada ou guardada em uma gaveta como coisa, existe para transformar a cidade onde ela floresceu. (BOSI, 2012, p.199)

\section{5. $O$ instante e o pós da tragédia}

A história oral começou a ser utilizada nos anos 1950, após a invenção do gravador, nos Estados Unidos, na Europa e no México, e desde então difundiu-se bastante. Ganhou também cada vez mais adeptos, ampliando-se o intercâmbio entre os que a praticam: historiadores, antropólogos, cientistas políticos, sociólogos, pedagogos, teóricos da literatura, psicólogos e outros. ${ }^{3}$ No livro Vozes de Tchernóbil (2012), a jornalista e escritora bielorrussa Svetlana

\footnotetext{
${ }^{3}$ CPDOC, O que é história oral. Disponível em <https://cpdoc.fgv.br/acervo/historiaoral>. Acesso em 5 jun. 2019.
} 
Aleksiévitch registra memórias de personagens que viveram o horror do desastre nuclear, por meio da história oral, metodologia de pesquisa que consiste em realizar entrevistas gravadas com pessoas que podem testemunhar sobre acontecimentos, conjunturas, instituições, modos de vida ou outros aspectos da história contemporânea. Conversou durante quase vinte anos com ex-trabalhadores da central, cientistas, médicos, soldados, evacuados, residentes ilegais em zonas proibidas. O trabalho dela serviu como referência para a abordagem das entrevistas com as vítimas em Bento Rodrigues.

Svetlana se dedica ao que chama de história omitida, "aos rastros imperceptíveis da passagem do homem pela Terra e pelo tempo" (ALEKSIÉVITCH, 2016). Ela fala sobre o deslocamento de realidade de um grupo afetado por uma tragédia:

Em apenas uma noite nos deslocamos para outro lugar da história. Demos um salto para uma nova realidade, uma realidade que está acima do nosso saber e acima da nossa imaginação. Rompeu-se o fio do tempo. O passado de súbito surgiu impotente, não havia nada nele em que pudéssemos nos apoiar; e no arquivo onipotente... Mais de uma vez ouvi naqueles dias: "Não encontro palavras para expressar o que eu vi e vivi "; "Ninguém antes me contou nada parecido"; "Nunca li nada semelhante em livro algum, nem vi algo assim em filme algum". Entre o momento em que aconteceu a catástrofe e o momento em que começaram a falar dela, houve uma pausa, um momento de mudez. E todos se lembram dele. (ALEKSIÉVITCH, 2016, p.41)

A escritora Eclea Bosi afirma que os depoimentos coletados devem deixar de ter um caráter de restauração do passado e passar a ser a memória criadora do futuro: memória social, histórica e coletiva. Para isso, o pesquisador, ao interpretar essas lembranças, deve pensar, como "cientista humano", em um projeto e no tipo de conhecimento está buscando e produzindo. Segundo ela, o passado reconstruído não pode ser um refúgio, mas deve ser uma fonte, um manancial de razões para lutar.

A fala emotiva e fragmentada do nosso memorialista é portadora de significações que nos aproxima da verdade. Nós temos que aprender a amar esse discurso tateante, as suas pausas, as suas franjas, com fios perdidos quase irreparáveis. Bem mais que um documento unilinear, a narrativa da testemunha mostra a complexidade do real. Oferece uma via privilegiada para compreender a articulação dos movimentos da história com a cotidianidade. É muito belo escutar esse rememorar meditativo da testemunha. E então compreendemos que se pode fazer da memória um apoio sólido para a construção do presente, e ela se torna para nós uma verdadeira matriz de projetos. (BOSI, 2012, p.197)

A conceito de memória social, história e coletiva de Bosi é reforçado pela ideia de que 
"fazemos apelo aos testemunhos para fortalecer ou debilitar, mas também para completar, o que sabemos de um evento do qual já estamos informados de alguma forma" (HALBWACHS, 1990, p.25). Assim, presença desses depoimentos é uma resistência, como nesta fala de Cristiano Sales:

A gente pensava que a Santarém (barragem de água) é que podia estourar. Mas, se isso acontecesse, só iria atingir a parte da igreja. O pessoal da Samarco sempre fazia reunião com os moradores de Bento e diziam: fiquem tranquilos, a barragem é segura. Não rompe. (BUENO, 2016)

Pollak se interessa pela forma com que a história oral pode intervir no trabalho de constituição e de formalização da memória coletiva. Privilegiando a narrativa dos excluídos, dos marginalizados e das minorias, a história oral, a seu ver, destaca a relevância de "memórias subterrâneas que, como parte integrante das culturas minoritárias e dominadas, se opõem à 'memória oficial'", conformadora de memórias coletivas nacionais (POLLAK, 1989, p. 4). A visão empática do sociólogo para com os grupos dominados reafirma o lugar da periferia e da marginalidade e evidencia o traço destruidor, uniformizador e opressor da memória coletiva nacional. Ele acredita que essas memórias subterrâneas continuam seu trabalho de subversão de maneira quase indistinta e emergem em momentos de crise em sobressaltos bruscos e exacerbados, como é o caso do desastre em Bento Rodrigues.

Segundo o relatório final da força-tarefa do Ministério Público Federal de Minas Gerais e do Espírito Santo, que investigou o desastre, o comando da Samarco e das suas duas controladoras - a brasileira Vale e a anglo-australiana BHP Billiton - sabiam da possibilidade de rompimento da barragem desde quando a estrutura entrou em operação, em 2009. Os procuradores reuniram, entre outros documentos, todas as atas de reunião do conselho da Samarco, com a presença dos representantes da Vale e da BHP. O MP concluiu que todos estavam cientes de que a estrutura apresentava problemas recorrentes, e embora tenham sido alertados várias vezes sobre o risco iminente do rompimento da barragem, não se preocuparam em evitar a tragédia (DIEGUEZ, 2016).

Em 20 de outubro de 2016, os procuradores de Minas Gerais e Espírito Santo denunciaram 26 pessoas à Justiça por homicídio qualificado com dolo eventual, pelo risco de crime contra as pessoas e contra o meio ambiente. Entre eles, o presidente da Samarco, Ricardo Vescovi de Aragão, três representantes da Vale no conselho de administração da Samarco e três da BHP Billiton (SOUTO, 2019). Três anos após o desastre, ninguém foi preso. O processo envolvendo executivos das três empresas ainda tramita na Vara Federal de Ponte Nova, sem data para julgamento. Apenas uma das 68 multas aplicadas por órgãos ambientais está sendo 
paga (em 59 parcelas). Apesar de as vítimas terem obtido na Justiça estadual benefícios como o aluguel de residência, auxílio financeiro mensal e assessoria técnica para começar a refazer a vida, elas ainda lutam por indenização e aguardam a construção de Novo Bento (SOUTO, 2019).

\section{Considerações finais}

A pesquisa ressalta a importância do resgate da memória de um povo devastado por um crime ambiental. Os depoimentos reforçam a importância de preservar a memória da comunidade. Os moradores de Bento continuam voltando à terra arrasada em resistência ao fim da história do lugar. Merece ser retomado o depoimento de Sales que descreve a situação de voltar às ruínas: "Falam que Bento acabou. Mas, para mim, não acabou, não. Eu volto lá e vejo. Sinto-me bem em ir lá e ver. Mesmo que esteja tudo destruído". Ele reforça a importância do lugar na manutenção da memória: "Tem que lembrar, né? Graças a Deus a gente ficou vivo e isso não deixou apagar essa memória da gente. Apagar não apaga. Ali não acaba não. Aquilo vai ficar pro eterno" (SALES, 2016).

O resgate dessas memórias é importante para a continuação da história dessa comunidade. Os entrevistados haviam perdido todos os referenciais físicos do passado. Além disso, a reunião dessas narrativas é fundamental na construção do Novo Bento. Eclea Bosi afirma que os pesquisadores devem ter a consciência de que essas narrativas coletadas não são feitas para serem arquivadas, mas sim para transformar a cidade de onde elas surgem. Bosi defende que, na criação de novos projetos, os urbanistas devem "escutar os velhos moradores e estar abertos a sua memória, que é a memória de cada rua, de cada bairro. Eles estariam recuperando a dimensão humana do espaço que é um problema político dos mais urgentes" (BOSI, 2012, p. 199).

O estudo incentiva a criação de novos espaços de memória. Pierre Nora explica que o momento de transição e a consciência de uma ruptura com o passado se mescla ao sentimento de uma abertura da memória: "... e é mesmo um momento, pois essa abertura ainda libera tanta memória que cabe perguntar-se pela possibilidade de sua corporificação. É por não haver mais milieux de mémoire que há tantos lieux de mémoire" (in ASMANN, 2011, p. 360$)$. 
Os depoimentos reforçam a luta contra a impunidade das empresas responsáveis pelo crime e se posicionam contra o esquecimento da tragédia pela sociedade. As vozes são um alarme para evitar crimes ambientais e o desaparecimento de cidades, como aconteceu em seguida em Brumadinho, MG. As narrativas coletadas nessa pesquisa podem se transformar em memória social: esses fragmentos de narrativas têm o poder de construir uma nova realidade.

\section{Referências bibliográficas}

AGÊNCIA BRASIL. Dossiê da UFMG propõe tombamento de distrito destruído em Mariana. Uol Notícias, 30 mai. 2019. Disponível em <https://noticias.uol.com.br/ultimasnoticias/agencia-brasil/2019/05/30/dossie-da-ufmg-propoe-tombamento-de-distritodestruido-em-mariana.htm>. Acesso em 15 jun. 2019.

ALEKSIÉVITCH, Svetlana. Vozes de Tchernóbil. Tradução Sonia Branco. São Paulo: Companhia das Letras, 2016.

ASSMAN, Aleida. Espaços de recordação: formas e transformações da memória cultural, tradução Paulo Soethe. Campinas, SP: Editora da Unicamp, 2011. BLANCHOT, Maurice. A escrita do desastre (fragmentos caídos de um texto ardente). Trad. João Rocha. Em Tese v. 21, n. 2, Belo Horizonte, maio-agosto 2015. BOSI, Eclea. Memória: enraizar-se é um direito fundamental do ser humano. Entrevista a Mozahir Salomão Bruck. Revista Dispositiva, v.1, no 2, ago/dez. PUC Minas, 2012, p. 196-199. Disponível em < http://periodicos.pucminas.br/index.php/ dispositiva/article/view/4301>. Acesso em: 10 set. 2015. BUENO, Cecília. Mariana: moradores fazem romaria em área soterrada por desastre da Samarco. Jornal da PUC Online, Mariana e Bento Rodrigues, 19 dez. 2016. Disponível em <http://jornaldapuc.vrc.puc-rio.br/cgi/cgilua.exe/sys/ start.htm?from_info_index=28\&infoid=4720\&sid=50>. Acesso em 4 jul. 2019. . Entrevistas realizadas com moradores de Bento Rodrigues em abril de 2016. DIEGUEZ, Consuelo. Vale e BHP sabiam do risco de desmoronamento da barragem da Samarco, diz relatório do MP. Revista Piauí, Rio de Janeiro, 3 nov. 2016. Disponível em $<$ https://piaui.folha.uol.com.br/vale- e-bhp-sabiam-do-risco-de- desmoronamento-dabarragem-da-samarco/>. Acesso em 23 jun. 2019. HALBWACHS, Maurice. A Memória Coletiva. São Paulo: Edições Vértice, 1990. MELO, Alice. Images of chaos: constructive narrative, fictions of memory and televised installation of 'Mariana Tragedy'. In: Mnemonics: Network for Memory Studies 2018. Ecologies of Memory. Irish College, Leuven, Belgium, 2018. 
NORA, Pierre. Entre memória e história: a problemática dos lugares In: Projeto História, São Paulo, n.10, p.7-28, dez.1993.

POLLAK, Michael. Memória, esquecimento, silêncio. In: Estudos Históricos. Rio de Janeiro, vol. 2, n 3, 1989.

SOUTO, Isabella. Três anos depois, ninguém foi condenado por tragédia de Mariana; processo na Justiça não tem data para julgamento. Jornal Estado de Minas, Belo Horizonte, 26 jan. 2019. Disponível em <https://www.em.com.br/app/noticia/gerais/2019/01/26/interna_gerais,1024701/tresanos-depois-ninguem-foi-preso-pela-tragedia-de-mariana.shtml>. Acesso em 25/06/2019. VALE, João Henrique do; RICCI, Larissa. Primeiras casas do novo Bento Rodrigues vão começar a ser construídas com atraso. Jornal Estado de Minas, Belo Horizonte, 21 mai. 2019. Disponível em <https://www.em.com.br/app/noticia/gerais/ 2019/05/21/interna_gerais,1055499/primeiras-casas-do-novo-bento-rodrigues-vaocomecar-a-ser-construidas.shtml>. Acesso em 14 jun. 2019. 